\title{
Fixing the Patent Office ${ }^{*}$ \\ Mark A. Lemley**
}

\begin{abstract}
How can we allow patent examiners to effectively distinguish between patentable and unpatentable inventions, without slowing the process to a crawl or wasting a bunch of money? This essay reviews the recent literature and considers a number of proposals and their limitations. It concludes that the system can be improved, but that we are unlikely to solve the problem of bad patents altogether. The focus in reform discussions should be on understanding and changing applicant and examiner incentives rather than simply spending money.
\end{abstract}

\section{The Problem of Bad Patents}

The Patent and Trademark Office (PTO) finds itself caught in a vise. On the one hand, it has been issuing a large number of dubious patents over the past twenty years, particularly in the software and electronic commerce space. It issues many more patents than its counterparts in Europe and Japan; ${ }^{1}$ roughly three-fourths of applicants ultimately get one or more patents, a higher percentage than in other countries. ${ }^{2}$ Complaints about those bad patents are legion, ${ }^{3}$ and indeed when they make it to litigation they are quite often held invalid. ${ }^{4}$ Even the ones that turn out to be valid are often impossible to understand; in the information technology industries, there is no lawsuit filed in which the parties don't fight over the meaning of patent claim terms. ${ }^{5}$

The natural reaction is to say that the PTO needs to do more than it does to make sure it is awarding patents only to those who deserve them. In fact, however, only some - not all - of these bad patents have significant social costs. Most patents don't matter. They claim technologies that ultimately failed in the marketplace. They protect a firm from competitors who for other reasons failed to materialize. They were acquired merely to signal investors that

\footnotetext{
* C 2012 Mark A. Lemley.

** William H. Neukom Professor, Stanford Law School; partner, Durie Tangri LLP. Thanks to Jonas Anderson, Colleen Chien, Peter Detkin, Rose Hagan, Naomi Hausman, Josh Lerner, Scott Stern, Stu Soffer and participants in workshops at the National Bureau of Economic Research, Marquette Law School and the J. Reuben Clark Legal Society for comments.

${ }^{1}$ Bruno Van Pottelsberghe de la Potterie, "The Quality Factor in Patent Systems" (working paper 2010027, European Center for Advanced Research in Economics and Statistics, 2010).

2 Mark A. Lemley and Bhaven Sampat, "Is the Patent Office a Rubber Stamp?" Emory Law Review. 58 (2008):181.

3 Jaffe, Adam, and Josh Lerner. 2004. Innovation and Its Discontents. Harvard University Press.

${ }^{4}$ John R. Allison and Mark A. Lemley, "Empirical Evidence on the Validity of Litigated Patents," AIPLA Quarterly Journal 26 (1998):185; John R. Allison et al., "Patent Quality and Settlement Among Repeat Patent Litigants," Georgetown Law Journal 99 (2011): 677.

5 Bessen, James, and Michael Meurer. 2008. Patent Failure: How Judges, Bureaucrats and Lawyers Put Innovation at Risk. Princeton University Press.
} 
the relevant firm has intellectual assets. Or they were lottery tickets filed on the speculation that a given industry or invention would take off. Those patents will never be licensed, never be asserted in negotiation or litigation, and thus spending additional resources to examine them would yield few benefits.

Some bad patents, however, are more pernicious. They award legal rights that are far broader than what their relevant inventors actually invented, and they do so with respect to technologies that turn out to be economically significant. Many Internet patents fall into this category. Rarely a month goes by that some unknown patent holder does not surface and claim to be the true inventor of eBay or the first to come up with now-familiar concepts like hyperlinking and e-commerce. While some such Internet patents may be valid-someone did invent those things, after all-more often the people asserting the patents actually invented something much more modest. But they persuaded the Patent Office to give them rights that are broader than what they actually invented, imposing an implicit tax on consumers and thwarting truly innovative companies who do or would pioneer those fields. ${ }^{6}$

Compounding the problem, bad patents are too hard to overturn. Courts require a defendant to provide "clear and convincing evidence" to invalidate an issued patent. ${ }^{7}$ In essence, courts presume that the Patent Office has already done a good job of screening out bad patents. Given what we know about patents in force today, that is almost certainly a bad assumption.

The problem, then, is not that the Patent Office issues a large number of bad patents. Rather, it is that the Patent Office issues a small but worrisome number of economically significant bad patents and those patents enjoy a strong, but undeserved, presumption of validity. ${ }^{8}$

The conclusion one might draw from this is that Patent Office should focus its examination resources on important patents and pay little attention to the rest. In fact, however, the problem of fixing the PTO is more complex, as we will see in the next Part.

\section{Can the Problem Be Solved?}

\footnotetext{
6 See Catherine Tucker, "Patent Trolls and Technology Diffusion," http://www.nber.org/confer/2012/IPKE/Tucker.pdf (finding that patent troll litigation reduced incremental innovation among target firms).

7 There are other mechanisms for reexamination that do not begin with a presumption of validity; those may be more effective ways to challenge bad patents. I discuss them in more detail in the next Part.

8 Mark A. Lemley, Doug Lichtman, \& Bhaven Sampat, "What To Do About Bad Patents," Regulation, Winter 2005-06:10.
} 
How, then, can we fix the PTO, allowing examiners to effectively distinguish between patentable and unpatentable inventions, without slowing the process to a crawl or wasting a bunch of money?

\section{A. What Won't Work}

First, some things that likely won't work. These unsuccessful solutions fall into two general categories: (1) those that throw money at the problem, and (2) those that try to change examiner behavior without changing the structure of the examination process or the incentives examiners face.

Preventing fee diversion. The PTO is funded through user fees imposed on applicants and owners of issued patents. For much of the last twenty years, some of that fee revenue (typically 10-20 percent of it) has been diverted by Congress to general federal revenue. It is a commonplace among patent lawyers that the way to solve the PTO's problems is to stop fee diversion, "fully funding" the PTO.

The America Invents Act walks a middle ground, preventing diversion of PTO fees to the general federal revenue, but requiring Congress to approve a budget for the PTO every year; revenue taken in but not appropriated is put in a "lockbox" and can only be held for later PTO spending. ${ }^{9}$ That won't satisfy those who wanted to end fee diversion as a means of increasing PTO funding, and it won't enable the PTO to predict years in advance what its budget is likely to be, but it will at least make fee diversion more difficult.

Stopping fee diversion will avoid taxing innovators in particular to raise general revenue, as we have done in the past. But stopping fee diversion is hardly a panacea. In the last several years, the PTO has been fully funded - that is, Congress didn't divert fees. Nonetheless, the application backlog grew. The addition of 10 to 20 percent of operating revenue wasn't enough even to enable the PTO to hold steady. It is naïve to assume that a modest increase in revenue can fix the problems that beset the PTO, particularly if that additional funding is not accompanied by any change in examiner incentives.

Fee-setting authority. In recent years the PTO's efforts have shifted to seeking permission from Congress to set their own fees. ${ }^{10}$ Until 2011 fees for patent applications were set by statute. ${ }^{11}$ The America Invents Act for the first time gives the PTO the power to set fees. Those fees must

9 America Invents Act $\S \_$__ Stat. __ (2011).

${ }^{10}$ Arti K. Rai, "Growing Pains in the Administrative State: The Patent Office's Troubled Quest For Managerial Control," University of Pennsy/vania Law Review 157 (2009): 2051.

11 The issue is bound up with the larger question of the role of the PTO as a full-fledged administrative agency with rulemaking authority. For discussion of that issue, see, e.g., Benjamin, Stuart Minor, and Arti K. Rai. 2008. "Fixing Innovation Policy: A Structural Perspective." George Washington Law Review 77:1; Thomas, John R. 2002. "The Responsibility of the Rulemaker: Comparative Approaches to Patent Administration Reform." Berkeley Technology Law Journal 17:727; Vertinsky, Liza. 2010. "Comparing Alternative Institutional Paths to Patent Reform." Alabama Law Review 61:501. 
be set at a level that recoups costs, ${ }^{12}$ though that appears to be a general rather than a specific requirement; the PTO can, for instance, charge substantial maintenance fees for existing patents even though maintaining a patent once granted costs the PTO nothing. The new feesetting authority will allow the PTO to (presumably) raise fees on applicants and patentees, using the money to pay for a more intensive examination.

Giving the PTO the authority to set its own fees might or might not be a good idea, depending on the relative incentives the PTO and Congress have to set fees rationally. The PTO is probably the better decision-maker; certainly PTO-set fees offer more flexibility than would a requirement to pass a new law every time fees need to change. But fee-setting authority shouldn't be viewed as a way to solve the problem of bad patents merely by enabling examiners to do more work. As noted above, it is not clear we should spend more money to weed out bad patents. Most of that money will be wasted on applications that are of no consequence to anyone. And because of the structure of the examination system, it might not even succeed in weeding out bad patent applications.

Even if it did, however, the current fee structure makes patent quality self-limiting. The PTO is paid by applicants to process their applications at each stage. But those payments are not enough even to sustain the limited examination that now occurs. The difference is made up by patent "maintenance fees" - periodic payments made by the owners of issued patents to keep those patents in force. Because the PTO's ability to examine new applications is dependent on revenue from previously granted ones, the PTO faces a problem: the more bad applications it rejects, the fewer patents will pay maintenance fees, and the less money it will have to conduct a detailed examination. The PTO ran into this problem in the late 2000s, when-as a result of a lowered grant rate coupled with companies abandoning patents during the recession-it found itself in a financial crisis. The broader lesson should be clear (and troubling): the current system for funding the PTO works only if the PTO continues to issue patents on a large percentage of the applications it receives. ${ }^{13}$

The PTO might begin to address this problem by changing the way it collects fees. At one extreme, it could abandon maintenance fees altogether, and pay for enhanced examination through higher application fees. ${ }^{14}$ That solves the self-limiting problem, but it raises the cost to startups seeking patents at an early stage of development, which doesn't seem ideal. Alternatively, the PTO could simply raise the maintenance fees significantly, to perhaps ten times their current rate. ${ }^{15}$ Doing so might make the weeding out of bad patents

12 America Invents Act $\S \_$__ Stat. __ (2011).

13 Cf. Micheal Frakes \& Melissa Wasserman, Does Agency Funding Affect Decisionmaking? An Empirical Assessment of the PTO's Granting Patterns (working paper 2012) (sustainability concerns may bias patent granting decisions in order to generate more fees, even if the agency isn't self-interested).

14 Melissa F. Wasserman, "The PTO's Asymmetric Incentives: Pressure to Expand Substantive Patent Law," Ohio State Law Journal 72 (2011):379, 432-35.

15 Some scholars have proposed this. See Baudry, Marc \& Beatrice DuMont, 2005. "Patent Renewals as Options: Improving the Mechanism for Weeding Out Lousy Patents," Review of Industrial Organization 28:41. 
revenue neutral, though as more bad applications are rejected the tax on those who actually obtained patents would have to increase further to compensate. And as the PTO raises its maintenance fees, fewer people will choose to maintain their patents. Depending on the elasticity of demand, paying for examination out of higher maintenance fees may or may not work.

Some have suggested raising maintenance fees for a different reason-to prevent patent lawsuits by trolls who buy up patents in order to enforce them. But that is unlikely to work. According to a 2009 American Intellectual Property Law Association (AIPLA) report, the median cost of taking a major patent case to trial is $\$ 5$ million per side in attorney's fees. ${ }^{16} \mathrm{~A}$ maintenance fee of $\$ 40,000-\$ 50,000$-ten times the current fee-may weed out more patents that aren't being used, but it is unlikely to deter someone considering spending perhaps 100 times that much to litigate a patent. ${ }^{17}$ And the patents that aren't being used aren't really the problem. Raising maintenance fees - or making them progressively higher toward the end of a patent life - would, however, weed out patents that sit on a shelf now but might be sold in the future to a troll that will assert them against product companies. In that sense it might reduce the number of troll lawsuits. And that might be enough; Brian Love has shown that most troll suits are filed in the last three years of a patent's life. ${ }^{18}$

Fee-setting authority may enable the PTO to manage other aspects of patent practice more effectively as well. For instance, fees proposed in February 2012 set very high fees for filing RCEs. That may do what the office has so far been unable to do: reduce the incidence of continuation practice. (More on this below).

Fee changes, then, offer some promise to improve certain aspects of patent practice. But the effects of using the tool are surprisingly complex, and it is not obvious the PTO can (or will have the incentive to) use that authority to fundamentally restructure the examination system.

Rejecting bad patents. Maybe the solution to the problem of bad patents is simply for the PTO to reject more dubious applications. If the same examiners simply applied a higher standard, on this view, fewer bad patents would slip through the PTO.

Leaving aside the question of whether the PTO has the power to change the substantive standards for patent examination (more on that later), ${ }^{19}$ it is not clear that we can or should

\footnotetext{
${ }^{16}$ American Intellectual Property Law Association. 2011. 2011 Report of Economic Activity.

17 Even if the lawsuit settles, as most do, parties can anticipate spending a median of $\$ 3$ million per side litigating the case through discovery. $I d$.

18 Love, Brian, 2012. "An Empirical Study of Patent Litigation Timing: Could a Patent Term Reduction Decimate Trolls Without Harming Innovators?," available at http://papers.ssrn.com/sol3/papers.cfm?abstract id=1917709

19 Theoretically the PTO merely applies the law set by Congress and the courts; it does not receive deference to its interpretations of that law. For an argument that the PTO nonetheless has a significant effect on substantive patent standards, generally in the direction of expanding patent rights, see Melissa
} 
weed out all bad applications at the PTO. The vast majority of patents are never litigated or licensed; spending a lot of money to ensure their validity would be wasted. ${ }^{20}$ And mistaken rejections impose costs as well; the goal should be to increase accuracy, not simply to trade off type I with type II errors.

The structure of the patent prosecution process makes it very difficult for the PTO to do so. As Sean Seymore has pointed out, the current law presumes that applications are patentable, not unpatentable. ${ }^{21}$ Patent examiners can never finally reject a patent application; applicants dissatisfied with the outcome can come back an unlimited number of times to try again through various mechanisms. ${ }^{22}$ Efforts beginning in 2006 to change that rule upset patent lawyers a great deal, and were ultimately abandoned. ${ }^{23}$ And because of the inability of the PTO to finally reject applications, when the PTO started making it harder to get patents several years ago, the result was to create an enormous backlog of patent applications as examiners would reject applications and applicants would try again (and again, and again) to get a patent. That backlog in turn created its own set of problems, delaying the issuance of good patents and reducing certainty for both applicants and third parties.

Some have suggested that those delays - and the use of continuation applications more generally-are the result of oddities in the system for evaluating and rewarding patent examiners. The so-called "count" system gave credit to examiners for certain acts; patent lawyers often complain that examiners "make" them file continuations in order to boost their counts. Whether or not that was true, however, it doesn't appear to be behind the growth of continuation applications. The PTO changed the count system in 2009 to try to address this problem. And it has been issuing record numbers of patents in recent years. But preliminary data from Dennis Crouch suggests that the number of continuation applications is still on the rise, up 27 percent from 2009 to $2010,{ }^{24}$ and the number of related Requests for Continued Examination reached record levels in 2011 - 53\% of all applications - despite these efforts. ${ }^{25}$ The data suggests that the use of continuations is largely applicant- rather than examiner driven.

F. Wasserman, "The PTO's Asymmetric Incentives: Pressure to Expand Substantive Patent Law," Ohio State Law Journal 72 (2011):379.

${ }^{20}$ Mark A. Lemley, "Rational Ignorance at the Patent Office," Northwestern University Law Review 95, no. 4 (2001).

21 Seymore, Sean, "The Presumption of Patentability," Minnesota Law Review (forthcoming 2012), available at http://papers.ssrn.com/sol3/papers.cfm?abstract_id=2012897

${ }^{22}$ Mark A. Lemley and Kimberly A. Moore, "Ending Abuse of Patent Continuations," Boston University Law Review 84 (2004): 63.

${ }^{23}$ Tafas v. Kappos, 586 F.3d 1369 (Fed. Cir. 2009).

24 Dennis Crouch, "Requests for Continued Examination Continue to Rise," Patently-O, http://www.patentlyo.com/patent/2010/07/requests-for-continued-examination-continue-to-rise.html (2010).

${ }^{25}$ Harold Wegner, email communication, February 27, 2012. 
The ability of applicants to file an unlimited number of continuation applications - and their willingness to do so - makes it difficult for examiners to simply reject bad applications.

Applicants view a rejection as simply a negotiating position that invites a counteroffer, not as a judgment that their application is in fact unpatentable. And because they can continue making counteroffers, increasing the number of rejections simply prolongs the application process.

In short, as long as the structure of the patent prosecution process remains unchanged, we cannot expect to solve the problem simply by having examiners reject more patents.

Retaining patent examiners. Another problem commonly cited by patent lawyers is the high rate of turnover at the PTO. Being an examiner is not an easy job, and it doesn't pay all that well. Not surprisingly, examiners often leave relatively quickly for jobs in engineering, jobs in law firms, or to go to law school. Indeed, one recent study found the median examiner had been at the PTO for just over three years. ${ }^{26}$ The high rate of turnover means that the PTO needs to hire more than 1,000 examiners a year just to keep even with attrition. In recent years the PTO has found it virtually impossible to grow the examining corps. And of course those new examiners must be trained. Perhaps the solution to the PTO's problems, then, is to find ways to keep those examiners from leaving.

There may well be benefits to reducing examiner attrition. But the evidence suggests that weeding out bad patents is not among them. One recent study shows that junior patent examiners are a lot more zealous in weeding out bad patents than senior examiners. The longer examiners spend in the PTO, the less searching they do, the fewer references they cite, the more likely they are to grant patents, and the more likely they are to grant patents on applications that their counterparts in other countries have rejected. ${ }^{27}$ The effects are quite large and statistically significant; the key data is reported in the Appendix (Table 1). The reason is not precisely clear, but may have to do with increased workloads on senior examiners, or with acculturation into a corps whose ethos is to grant rather than deny patents. Either way, it is the most junior examiners who are most likely to reject applications. Therefore, keeping examiners around longer may hurt rather than help the cause of weeding out bad patents.

Outsourcing search. Reacting both to workload and to a sense that examiners don't find the most important prior art, a number of initiatives both within and outside the PTO have tried to relieve examiners of the burden of searching for prior art. They have variously proposed to require the applicants to do their own search for prior art, $^{28}$ to invite the public to review applications and submit prior art, ${ }^{29}$ or to share the burden of searching with patent examiners

\footnotetext{
${ }^{26}$ Mark A. Lemley and Bhaven Sampat, "Examiner Characteristics and Patent Office Outcomes," Review of Economics \& Statistics forthcoming (2012).

${ }^{27}$ Id.

${ }^{28}$ There is currently no such requirement.

${ }^{29}$ Beth Simone Noveck, "'Peer to Patent': Collective Intelligence, Open Review, and Patent Reform," Harvard Journal of Law and Technology 20 (2006): 123.
} 
in other countries. ${ }^{30}$ Work-sharing programs among patent offices are quite common, and the PTO is aggressively expanding them. ${ }^{31}$ These initiatives seem promising because they outsource a function examiners don't seem particularly good at-finding the most relevant information on the ground-to others who are positioned to do it better.

But recent empirical evidence suggests that outsourcing might not work. Cotropia et al. studied the behavior of patent examiners in responding to applications, and found that they rely almost exclusively on art they find for themselves, not art submitted by applicants. And that doesn't appear to reflect either applicants drafting around the art they found or the weakness of that art; U.S. examiners did not rely even on art that was submitted because it was found important by a foreign patent examiner during examination of a counterpart application. ${ }^{32}$ The effects are extremely large and statistically significant; key data is reported in the Appendix (Table 2). The effect cannot be explained by applicant behavior, and seems to be a result of examiner decisions to focus attention on art they found for themselves rather than applicant-submitted art. If examiners are psychologically primed to rely principally on things they find for themselves, it won't help to have others provide them with the best art. And it might even hurt, causing examiners not to focus on the best prior art. More generally, the implication of this evidence is that we need to pay attention not only to legal rules, but also to examiner behavior and reward systems.

\section{B. What Might Work}

The problems with the PTO are deep rooted. Increased funding won't solve the problem of bad patents, and a variety of other commonly suggested fixes for the PTO are unlikely to solve the problem, and indeed could even make it worse.

Other proposals have a greater chance of addressing the problem of bad patents, though they come with their own uncertainties.

Second pair of eyes. Shortly after the Federal Circuit held business methods patentable in 1998, the PTO was inundated with business method patent applications. Most of those applications went to Class 705, which refers to the collection of patent examiners who focus on business methods. Indeed, by 2001, Class 705 had the largest application volume. In response to this flood, the PTO initiated a specific "quality control" measure in this class in March 2000: the "second pair of eyes" review (SPER), under which applications are subjected to mandatory assessment by more than one examiner before being allowed. ${ }^{33}$ Requiring two examiners to

\footnotetext{
${ }^{30}$ Michael Abramowicz \& John F. Duffy, "Ending the Patenting Monopoly," 157 U. Pa. L. Rev. 1541, 1554 (2009).

${ }^{31}$ http://www.uspto.gov/ip/global/patents/ir pat worksharing.jsp.

${ }^{32}$ Cotropia et al., "Do Applicant Patent Citations Matter?" supra. The evidence is presented in more detail in Tables 4-6.

${ }^{33}$ John R. Allison and Starling D. Hunter, "On the Feasibility of Improving Patent Quality One Technology at a Time: The Case of Business Methods," Berkeley Technology Law Journal 21 (2006): 729.
} 
agree seems to have had a dramatic effect: a 2009 study found that class 705 has the lowest grant rate among high volume classes. ${ }^{34}$ One possible explanation for the low grant rate in this class is that the second pair of eyes was working, and that the grant rate reflects better rigor during examinations, rather than application volume. [That's not the only possible explanation; there might have been more low-quality applications in class 705 than in other classes].

The fact that SPER leads to more rejections in Class 705 doesn't mean it is an unalloyed success, however. Allison and Hunter demonstrate that its adoption in Class 705 led applicants to try to characterize their business method patents in ways that got them out of Class 705. It is possible that the applications that were not so characterized were systematically weaker (or their lawyers systematically less skilled) than the ones that avoided Class 705 . The differences Lemley and Sampat found were so striking, however-a 16.1 percent grant rate in Class 705, compared with 72 percent on average-that it seems unlikely this can explain the full difference.

Allison and Hunter's objection is significant. But it applies only to a class-specific use of SPER, and wouldn't condemn a broader application of the policy to all art units. Nonetheless, there are reasons to think carefully before expanding SPER to all patent applications. Doing so would roughly double the cost of patent prosecution across the board. It would also delay the prosecution process further; Class 705 applications are among the slowest to be processed. Further, at least as currently configured, SPER is asymmetric -it requires a second hurdle before allowing patents but not before rejecting applications. ${ }^{35}$ As a result, it is likely to weed out bad patents, but also to catch some good ones within the net of rejected applications, given the inherent tradeoff between type 1 and type 2 errors under uncertainty. Given the PTO's historic bias towards granting dubious patents, perhaps that is a risk worth taking, but it is still a social cost we should avoid if we can. And if SPER or some other review process is to be adopted, it would seem logical to apply it evenhandedly to grants and rejections.

The most logical use of SPER or an equivalent mechanism would be in conjunction with one of the mechanisms I discuss below that help to identify important patent applications. It may not be desirable to raise the cost to applicants across the board, for reasons I have discussed. But if we have reason to believe that a particular application is particularly important, it may justify more serious scrutiny.

Interestingly, the PTO recently shut down the SPER program in business methods. Too much success, it seems, carries its own risks.

\footnotetext{
${ }^{34}$ Lemley and Sampat, "Is the Patent Office a Rubber Stamp?" 2008.

35 There is a similar problem with the PTO's quality review mechanism, which reviews a random subset of grants. Examiners could be punished for mistaken grants if caught in the quality control process, but were not punished for mistaken rejections, which were never reviewed (Katznelson 2010). Effective October 1, 2010, the PTO changed its quality evaluation system to be more evenhanded, a clear improvement.
} 
Changing examiner incentives. Recent empirical evidence suggests that much of the problem with patent examination revolves around examiner incentives and human resource policies. ${ }^{36}$ Examiners do less well at policing bad patents the longer they stay at the PTO. The problem could be their distance from the technology, or a tenure effect, or their increased workload. In any case, changes in training, workload, or promotion rules could affect those incentives. Similarly, examiners pay attention to their own searches, and not prior art submitted by others. The problem could be overconfidence bias, or simply triage. Either way, human resource policies could be brought to bear, training examiners to search better, or giving them more time, or finding other ways to eliminate bias. And it seems obvious - though likely politically infeasible - that the rules should not treat allowances differently than rejections. ${ }^{37}$

These ideas are worth exploring further. Patent reform efforts to date have not focused sufficient attention on examiner behavior and incentives. But implementation may be politically difficult, both because the powerful examiners' union resists changes to the way examiners are evaluated and because patent prosecutors are likely to resist changes that make it harder for them to obtain patents. And some of the possible explanations point in different directions: should we give examiners more time to search, or less, for example? The answer may depend on whether we think the examiner bias towards their own search results can be reversed or should instead be accommodated.

Tiered review. The problem with the PTO is not precisely that it issues a large number of bad patents. Rather, it is that the PTO issues a small but worrisome number of economically significant bad patents and those patents enjoy a strong, but undeserved, presumption of validity. This suggests that the Patent Office should focus its examination resources on important patents and pay little attention to the rest. But it is difficult for the government to know ahead of time which patents are likely to be important.

There are two groups, however, that have better information about the likely technological and commercial value of inventions: patent applicants and competitors. To harness information in the hands of patent applicants, we could give applicants the option of earning a presumption of validity by paying for a thorough examination of their inventions. Put differently, applicants should be allowed to "gold plate" their patents by paying for the kind of searching review that would merit a strong presumption of validity. ${ }^{38}$ An applicant who chooses not to pay could still get a patent. That patent, however, would be subject to serious-maybe even de novo-review in the event of litigation. Most likely, applicants would pay for serious review with respect to their most important patents but conserve resources on their more

\footnotetext{
36 For discussion of the examiner-dependence of outcomes at the PTO, see lain Cockburn, Sam Kortum, \& Scott Stearn, "Are All Patent Examiners Equal? The Impact of Examiner Characteristics, in Cohen, Wesley and Steven Merrill (eds.) Patents in the Knowledge-Based Economy. National Academies Press, 2003.

${ }^{37}$ Ron Katznelson, "Patent Examination Policy and the Social Costs of Examiner Allowance and Rejection Errors." Stanford Technology Law Review (2010).

${ }^{38}$ Mark A. Lemley et al., "What To Do About Bad Patents," Regulation Winter 2005-2006 (2005): 10.
} 
speculative entries. ${ }^{39}$ That would allow the Patent Office to focus its resources on those selfselected patents, thus benefiting from the signal given by the applicant's own self-interested choice. The Obama campaign proposed this sort of tiered review, and the PTO has recently implemented a scaled-down version, in which applicants can choose the speed but not the intensity of review. ${ }^{40}$ Adoption has been significant but modest; neither those who feared that everyone would use the system nor those who feared no one would seem to be correct. Rather, it appears to be performing its intended function of distinguishing some urgent applications from the rest of the pack.

Tiered review is only as good as the examination process that creates it, however, and if "gold-plated" patents are too easy to obtain, the point of the system will be lost. If they are too hard to obtain or too expensive, by contrast, no one will use the system. In either event the signaling benefits will be lost. Further, tiered review can at best be only a partial solution, because applicants do not always have accurate information about the future value of their applications. These are real objections, but they do not undermine the value of some sort of targeting in the use of PTO examination resources.

Oppositions and adversarial evaluations. Competitors also have useful information about which patents worry them and which do not. A post-grant opposition system seeks to harness that information. Post-grant opposition is a process by which parties other than the applicant have the opportunity to request and fund a thorough examination of a recently issued patent. A patent that survives collateral attack should earn a presumption of validity similar to the one available through tiered review. The core difference is that the post-grant opposition is triggered by competitors - presumably competitors looking to invalidate a patent that threatens their industry.

Like tiered review, post-grant opposition is attractive because it harnesses private information; this time, information in the hands of competitors. It thus helps the PTO to identify patents that warrant serious review, and it also makes that review less expensive by creating a mechanism by which competitors can share critical information directly with the PTO.$^{41}$ A post-grant opposition system is part of the new America Invents Act, ${ }^{42}$ but it won't begin to apply for another several years, ${ }^{43}$ and the new system will be unavailable to many competitors because of the short time limits for filing an opposition. ${ }^{44}$

\footnotetext{
${ }^{39}$ For a more detailed working out of the tiered review proposal, see Douglas Lichtman and Mark A. Lemley, "Rethinking Patent Law's Presumption of Validity," Stanford Law Review 60 (2007): 45.

${ }^{40}$ Unfortunately, that proposal came with a bias against foreign applications that makes little sense as an economic matter, and may also render it suspect under U.S. treaty obligations.

${ }^{41}$ Lemley et al., "What To Do About Bad Patents."

${ }^{42}$ America Invents Act $\S \_$_ _ Stat. _ (2011).

43 Post-grant opposition is available only for patents granted on applications filed after April 16, 2013. Because the average time to grant is close to four years, it will likely be the latter part of this decade before many patents are eligible for post-grant opposition.

44 For example, the fact that a post-grant opposition must be filed within nine months after a patent is granted, America Invents Act $\S$ Stat. (2011), means that neither troll patents nor
} 
The success of post-grant opposition depends on the willingness of third parties with good information about the validity of a patent to challenge that patent in a public forum, rather than settling privately. Some commentators are skeptical; pointing out that invalidating patents is a public good that the challenger would share with every other competitor. ${ }^{45}$ But the evidence from operation of similar systems in Europe is encouraging. ${ }^{46}$

Patent law has other mechanisms that could be used to achieve the same goal. Some issued patents are returned to the PTO after issuance and are reevaluated through an adversarial process known as inter partes reexamination. This is an evaluation to which some deference is appropriate, though today the law gives complete deference to that determination by preventing a party challenging a patent in reexamination from raising many validity issues in court. Even traditional ex parte reexamination, while not truly adversarial, allows the filer to submit an initial explanation of the reasons for reexamination, and the result has been that in recent years patents fare worse in reexamination than applications do in initial examination.

The biggest risk with post-grant opposition and related systems is giving challengers too many bites at the apple, allowing them to inundate patentees with an endless set of challenges. One way to address that problem is to place some limits on the number and perhaps the timing of challenges, and to imbue patents that survive those challenges with a strong presumption of validity. The America Invents Act does just that, effectively requiring parties to choose one of these mechanisms to the exclusion of others.

\section{Living With Imperfection}

Reforms such as those I discussed in the last section could make the prosecution process more efficient and help to weed out bad patents at an acceptable cost. But none of them will solve the problem of bad patents, or even come especially close to doing so. Part of the process of patent reform must involve acknowledging the inherent imperfections in the patent examination process, and adapting to those imperfections.

pharmaceutical patents are likely to be challenged, since in neither case are competitors likely to know the patent is important shortly after it issues. See Love, supra (troll patents become important only at the end of their patent life).

${ }^{45}$ Christopher A. Cotropia, “Modernizing Patent Law's Inequitable Conduct Doctrine," Berkeley Technology Law Journal 24 (2009): 723; Joseph Farrell and Robert P. Merges, "Incentives to Challenge and Defend Patents: Why Litigation Won't Reliably Fix Patent Office Errors and Why Administrative Patent Review Might Help," Berkeley Technology Law Journal 19 (2004): 943.

46 Stuart J.H. Graham et al., "Patent 'Quality Control': A Comparative Study of US Patent Reexaminations and European Patent Oppositions," , in Cohen, Wesley and Steven Merrill (eds.) Patents in the Knowledge-Based Economy. National Academies Press, 2003. On the economics of the patent system in Europe, see Dominique Guellec \& Bruno van Pottelsberghe de la Potterie, The Economics of the European Patent System. Oxford University Press, 2007. 
In particular, we will continue to rely on litigation for the foreseeable future as a primary means for weeding out bad patents. Litigation elicits information from both patentees and competitors through the adversarial process, which is far superior to even the best-intentioned government bureaucracy as a mechanism for finding truth. ${ }^{47}$ More important, litigation is focused on the very few patents (1-2 percent) that turn out to be important and about which parties cannot agree in a business transaction.

Litigation can be abused, and examples of patent litigation abuse have been rampant in the last two decades. But a variety of reforms have started to bring that problem under control, and the courts have the means to continue that process. ${ }^{48}$

Part of the process must include a realistic recognition of the shortcomings of the patent prosecution system. There are various ways the law might achieve such a recognition. Courts could modulate the presumption of validity for issued patents. A presumption like that embraced by the current "clear and convincing" standard must be earned, and under current rules patent applicants do not earn it. We could replace that high hurdle with a more appropriate level of deference. And the presumption ought to reflect the realities of patent practice. The current presumption is so wooden that courts today assume a patent is valid even against evidence that the patent examiner never saw, much less considered, a rule that makes no sense. ${ }^{49}$ While the Supreme Court rejected application of the lower "preponderance of the evidence" presumption, ${ }^{50}$ the one currently given trademarks and copyrights, it encouraged courts to explain to juries that they should give less deference to the PTO with respect to prior art that was not before the PTO. ${ }^{51}$ And recent evidence suggests that such an instruction may be surprisingly effective in limiting the presumption of validity. ${ }^{52}$ So too is the growing treatment of patent validity in the courts as a question of law, not fact. For legal questions are not subject to the presumption of validity.

The presumption of validity should be dynamic, not static. Improvements to the patent prosecution process might justify a stronger presumption. In particular, surviving more extensive scrutiny, whether by opting into tiered review, being subject to an opposition proceeding, or perhaps even getting approval from two examiners rather than one, might justify a stronger presumption. A dynamic presumption will allow the courts to play their proper role as the guardians of the public interest while encouraging applicants and the PTO to shoulder their burden as well.

\footnotetext{
${ }^{47}$ Lichtman and Lemley, "Rethinking Patent Law's Presumption of Validity."

${ }^{48}$ Dan L. Burk and Mark A. Lemley, The Patent Crisis and How the Courts Can Solve It (Chicago: University of Chicago Press, 2009).

${ }^{49}$ Lemley et al., "What To Do About Bad Patents;" Lichtman and Lemley, "Rethinking Patent Law's Presumption of Validity."

50 Microsoft Corp. v. i4i Ltd., 131 S.Ct. 2238 (2011).

51 Id. at 2251.

${ }^{52}$ David L. Schwartz \& Christopher B. Seaman, The Presumption of Patent Validity: An Experimental Study (working paper 2012).
} 


\section{Appendix}

Table 1: Linear probability models relating whether an application is granted, and whether granted with no rejections, to examiner experience ${ }^{53}$

\begin{tabular}{|c|c|c|}
\hline & 4.1 & 4.2 \\
\hline & Was the application granted? & $\begin{array}{l}\text { Was the application granted } \\
\text { with no rejections? }\end{array}$ \\
\hline \multirow[t]{2}{*}{ 2-4 Years Experience } & $0.057 * * *$ & $0.060 * * *$ \\
\hline & $(0.013)$ & $(0.013)$ \\
\hline \multirow[t]{2}{*}{ 5-7 Years Experience } & $0.110 * * *$ & $0.111^{* * *}$ \\
\hline & $(0.018)$ & $(0.020)$ \\
\hline \multirow[t]{2}{*}{ 8+ Years Experience } & $0.112 * * *$ & $0.133^{* * *}$ \\
\hline & $(0.013)$ & $(0.015)$ \\
\hline \multirow[t]{2}{*}{ Constant } & $0.663 * * *$ & $0.105^{* * *}$ \\
\hline & $(0.009)$ & $(0.009)$ \\
\hline Art Unit Effects & Yes, Jointly Significant & Yes, Jointly Significant \\
\hline $\mathrm{N}$ & 9846 & 7117 \\
\hline
\end{tabular}

Notes: Omitted class for comparison is examiners with 0-1 years experience. Robust standard errors (clustered on examiners) reported in parentheses. Asterisks denote statistical significance:

$* \mathrm{p}<10 \%, * * \mathrm{p}<5 \%, * * * \mathrm{p}<1 \%$

53 Source: Mark A. Lemley and Bhaven Sampat, "Examiner Characteristics and Patent Office Outcomes," Review of Economics \& Statistics forthcoming (2012). 
Table 2: Multivariate Regression on Applicant-Provided References ${ }^{54}$

\begin{tabular}{|c|c|c|c|c|}
\hline & $\begin{array}{l}\text { Model 1: } \\
\text { Was the } \\
\text { reference used } \\
\text { in a rejection? }\end{array}$ & $\begin{array}{l}\text { Model 2: } \\
\text { Was the } \\
\text { reference used } \\
\text { in a rejection? }\end{array}$ & $\begin{array}{l}\text { Model 3: } \\
\text { Was the } \\
\text { reference used } \\
\text { in a rejection? }\end{array}$ & $\begin{array}{l}\text { Model 4: } \\
\text { Was the } \\
\text { reference used } \\
\text { in a rejection? }\end{array}$ \\
\hline $\begin{array}{c}\text { Non-Patent Reference? } \\
(1=\text { Yes })\end{array}$ & $-.098 * * *$ & $-.013^{*}$ & $-.077^{*}$ & $-.013^{*}$ \\
\hline $\begin{array}{l}\text { Foreign Reference? } \\
\qquad(1=\text { Yes })\end{array}$ & $-.105^{* * *}$ & 0.004 & $.120 * * *$ & 0.001 \\
\hline $\begin{array}{l}\text { Patent a continuation? } \\
\qquad(1=\text { Yes })\end{array}$ & $-.065^{* * *}$ & -0.008 & -0.008 & -0.005 \\
\hline $\begin{array}{l}\text { Patent a divisional? } \\
\qquad(1=\text { Yes })\end{array}$ & $-.048 * * *$ & -0.004 & -0.004 & -0.001 \\
\hline $\begin{array}{l}\text { Applicant Reference? } \\
\qquad(1=Y e s)\end{array}$ & & $-.352 * * *$ & & \\
\hline Applicant * Non-Patent & & & $-.282 * * *$ & \\
\hline Applicant ${ }^{*}$ Foreign & & & $-.476 * * *$ & \\
\hline Applicant * Patent & & & $-.352 * * *$ & \\
\hline Applicant * "Total & & & & \\
\hline $\begin{array}{l}\text { Citations in Patent" in } \\
\text { Bottom Quartile }\end{array}$ & & & & $-.339 * * *$ \\
\hline Applicant * "Total & & & & \\
\hline $\begin{array}{c}\text { Citations in Patent" in } \\
\text { 2nd Quartile }\end{array}$ & & & & $-.340 * * *$ \\
\hline Applicant * "Total & & & & \\
\hline $\begin{array}{l}\text { Citations in Patent" in } \\
\text { 3rd Quartile }\end{array}$ & & & & $-.340 * * *$ \\
\hline
\end{tabular}

54 Source: Christopher A. Cotropia et al., "Do Applicant Patent Citations Matter? Implications for the Presumption of Validity" (working paper, 2012). 


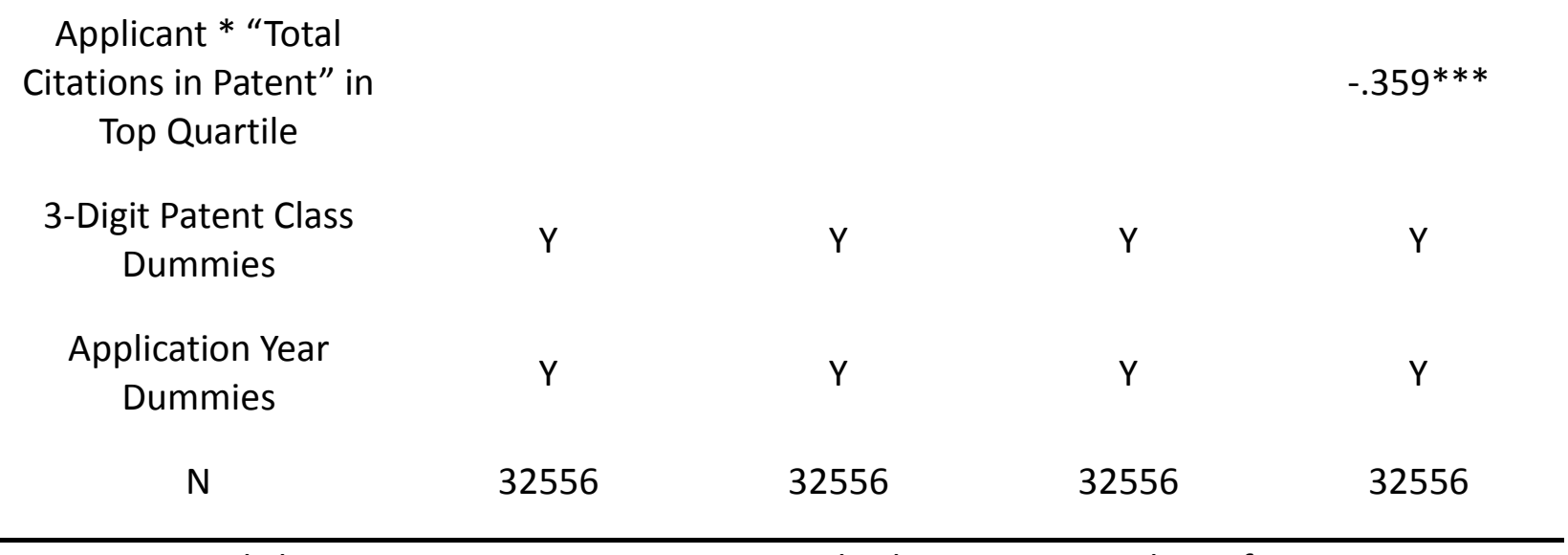

Notes: Omitted class is U.S. patent citations. Asterisks denote statistical significance:

$* p<10 \%,{ }^{* *} p<5 \%, * * * p<1 \%$ 